\title{
Å SKAPE DATA FRA KVALITATIVT
}

Samtale er en grunnleggende og kanskje den mest gyldige form for kunnskapsutvikling vi kjenner til.

Av Sigrun Drageset og Sidsel Ellingsen

\section{INNLEDNING}

Utgangspunktet for det kvalitative forskningsintervju er samtalen (1). Både ved kvantitativ og kvalitativ forskningstilnærming er intervju en grunnleggende datainnsamlingsmetode $(2,3,4,5)$. Søk i databasene Swemed og Cinahl i perioden: 1980-2009 viser en $\varnothing$ øende tendens til intervju som datainnsamlingsmetode både innen kvantitativ og kvalitativ forskning. Imidlertid kan denne økningen sees i sammenheng med antall tidsskrifter og et økende krav til registrering. Det er mye kvalitativ forskning innen humanvitenskapene, utgitt i bok eller monografiform, som aldri er blitt registrert eller er tilgjengelig i tidsskriftsdatabaser.

Hensikten med denne artikkelen er å tydeliggjøre intervjuprosessen, de etiske og dynamiske utfordringene $\mathrm{i}$ intervjusituasjonen og hvilken betydning dette har for datas gyldighet og pålitelighet. I tillegg vil vi belyse valg og utforming av intervjuguide.

\section{VITENSKAPSTEORETISK TILN/ERMING}

Forskerens kunnskapssyn har betydning for hvordan og hvilke data som innhentes og skapes (6). Creswell (7) belyser ontologi, epistemologi, verdisyn, retorikk og metode som fem ulike filosofiske antakelser forskeren må gjøre valg i forhold til ved gjennomføring av et forskningsprosjekt. Postpositivisme, konstruktivisme, diskurs og pragmatisme er fire sentrale forskningsparadigmer som på ulik måte kan representere forskerens kunnskapssyn og som er i stadig utvikling. Kvale \& Brinkman (8) belyser ulike aspekt ved kunnskap som er relevant for det kvalitative intervju belyst innen forskjellige filosofiske retninger. Sentrale tilnærminger er hermeneutikk, fenomenologi og pragmatisme, i tillegg til diskurs og dialektikk.

\section{ULIKE FORMER}

Kvalitative intervju blir ofte klassifisert som enten eksplorativt (utforskende) eller deskriptivt (beskrivende) $(9,10)$. Fontana \& Fray (2) skiller mellom strukturert, semistrukturert ustrukturert (åpent), gruppe- og postmoderne intervju. Kvale \& Brinkman (8) omtaler syv ulike former for forskningsintervju: 1) Datastøttende intervju ved hjelp av telefoni eller data- teknologi hvor forsker og informant er fysisk atskilt. 2) Fokusgruppeintervju som består av en gruppe på seks til ti informanter hvor fokus er å diskutere og konkretisere et tema. Gruppen blir ledet av en moderator og/eller en forsker (2,11). 3) Faktuelle intervju hvor hensikten er å innhente faktisk informasjon om en person eller et hendelsesforløp. 4) Begreps- eller fenomenintervju som har til formål å kartlegge eller utdype nyanser eller variasjoner av et fenomen som eksempelvis håp eller omsorg. 5) Narrative intervju hvor det søkes tilgang til intervjupersonens fortelling eller historie. 6) Diskursive intervju som har fokus på å få frem forskjeller, samt hvordan sosial og politisk dominans ytrer seg i samtale. 7) Konfronterende intervju hvor det produseres mening ved å utfordre tema slik at det skapes en konflikt og maktdimensjon i intervjuet (8).

\section{INTERVJUGUIDE}

En intervju- eller temaguide er et hjelpemiddel for å holde fokus på det som utforskes, da intervjuspørsmålene har til hensikt å åpne opp slik at fenomenet eller temaet blir belyst fra ulike perspektiv og vinkler. Intervjuguiden skal ta hensyn til det kvalitative intervjuets to dimensjoner: den teoretiske med hensyn til relevans for forskningsprosjektets problemstilling, samt den dynamiske for å skape en god intervjuinteraksjon (8). For å kunne stille relevante spørsmål er det nødvendig med god teoretisk kunnskap om feltet, samtidig er det viktig å være oppmerksom på distinksjon mellom teoristyrt og teoriladd intervjuguide. Ved teoristyrt intervjuguide styres intervjuspørsmålene av en eller flere valgte teorier. En teoriladd intervjuguide viser til god teoretisk kunnskap om temaet, men er ikke knyttet til en bestemt teori. Når intervjuguiden blir utarbeidet er det viktig å tenke på oppbygning av intervjuet. Det er sentralt å fokusere på: hva - temaet for unders $\varnothing$ kelsen, hvorfor - formålet med intervjuet og hvordan - intervjuteknikker, datainnhenting, transkribering og analyse. Intervjuspørsmålene har gjerne en deskriptiv form med hovedsakelig hva- og hvordan-spørsmål. For mange hvorfor-spørsmål kan hemme spontanitet og fyldige beskrivelser og dreie intervjuet fra å være beskrivende til å bli forklarende og argumenterende. Intervjuspørsmålene bør være korte og lette å forstå, og det er viktig at man unngår å spørre om flere ting på en gang $(8,9)$. Ved å gjenta de viktigste ordene i sva- 


\section{FORSKNINGSINTERVJU}

ret inviteres det til en fordypning i temaet. Det er ved denne fordypningen at fleksibiliteten blir synlig da man har mulighet til å løfte frem variasjoner og nyanser. Det også viktig å spørre hvordan informanten opplevde intervjusituasjonen da det har betydning for data som skapes og bør synliggjøres.

\section{INTERVJUSITUASJONEN}

Kvalitative forskningsmetoder innebærer møter mellom mennesker fra ulike levekår, med ulike livserfaringer, normer og verdier. Relasjon og kontekst utgjør viktige elementer av den kunnskapen som utvikles (12). Konteksten er ikke uvesentlig da rommet, omgivelsene og livsituasjonen til forsker og informant vil påvirke intervjusituasjonen. Ved en fenomenologisk hermeneutisk tilnærming er det et hovedpoeng at forskeren stiller seg åpen og sanselig stemt, slik at forsker lar seg berøre av det som informanten gir uttrykk for. Det er her den fenomenologiske dimensjon kommer til uttrykk. Holdningen som forsker uttrykker ved sin væremåte fargelegger toneleiet som bærer ordene, slik at samme spørsmål kan oppleves som arrogant, ironisk eller oppriktig $(1,8,13)$. Stemmeleie fargelegger ordet, samtidig som følelsene gir adgang til en situasjonsbetydning, og kan være en viktig døråpner til vesentlige aspekter ved temaet. Samtidig må det også vises varhet og ydmykhet overfor informantens grenser $(13,14)$. En åpen tilnærming til tema hvor både informant og intervjuer er engasjert og blir berørt medvirker til å skape ny kunnskap. Forskerens varhet og evne til åpenhet vil ikke bare prege intervjusituasjonen, men også kvaliteten på dataene som skapes. Utfordringen er å la informanten få tale ut og ikke bli avbrutt av forskers perspektiv, men ha en åpen innstilling og møte informantens opplevelser og erfaringer med utdypende og oppfølgende spørsmål. Det gir mulighet til økt forståelse og horisontutvidelse.

Bourdieu (15) var opptatt av å utøve en ikkevoldelig kommunikasjon i intervjusituasjonen. Det er en asymmetri mellom informant og forsker. Hvis det i tillegg er stor forskjell på sosial rang og kulturell og språklig kapital mellom informant og forsker, kan asymmetrien forsterkes og sjansen for å utøve voldelig kommunikasjon $\varnothing k e$. Dette kan vise seg i alt fra ordene forskeren bruker, hvordan studien blir presentert, forskerens forståelse, hva som vektlegges og hva som holdes tilbake. Det er derfor viktig å tenke over om man er rette person til å intervjue den aktuelle informanten. All sosial utveksling har en effekt som kan virke som en tilfeldig forstyrrelse hvis den ikke blir reflektert over. Det er et hovedpoeng for Bourdieu å være refleksiv og metodisk klar over og aktivt prøve å minske denne asymmetrien (15).

\section{ETISKE AVGJøRELSER}

Etiske regler og teorier kan sjelden gi konkrete svar på hvilke normative valg som skal foretas i løpet av et forskningsprosjekt. De gir retningslinjer som må vurderes i forhold til prosjektets spesifikke situasjoner. Etiske avgjørelser hører ikke til i noen enkelt del av intervjuundersøkelsen, men må vurderes gjennom hele forskningsprosessen (16). Selv om informanten har gitt et skriftlig informert samtykke kan han/hun være uforberedt på spørsmålet i en intervjusituasjon (17). Vi vet ikke hvilke erfaringer et annet menneske bærer på, og heller ikke hvilke spørsmål som kan virke sensitive eller utfordrende for informanten. Hvis uventede reaksjoner utløses bør man stoppe opp, og komme tilbake til temaet når informanten ønsker det. Uansett bør man vise varhet og ydmykhet for den andres grenser.

Å finne denne balansegangen er utfordrende og det er her håndverksmessig skjønn og etiske aspekter i intervjusituasjonen blir tydelig. Konsekvensen bør vurderes med hensyn til mulig skade, og eventuelle fordeler informantene kan ha ved å delta i et forskningsprosjekt. En sentral forskningsetisk forpliktelse er at forskeren ivaretar konfidensialitet og klargjør sin egen rolle i prosjektet.

\section{TRANSKRIBERING OG ANALYSE}

Det er ikke noe skarpt skille mellom datainnhenting, transkribering og analyse ved et kvalitativt forskningsintervju (8). Den som transkriberer er underlagt mange begrensninger som er vanskelige å etterfølge. Først og fremst må man være tro mot alt som kommer opp i intervjuet, samtidig som man ikke reduserer intervjuet til kun å gjelde det som er tatt opp på bånd. Det er mye som blir formidlet i taushet, i pausene mellom ordene, i sukk og av kroppens fremtoning, som blir fraværende ved ordrett transkribering (15).

Det finnes ulike analyseformer, noen er sterkt knyttet til vitenskapsteoretiske tradisjoner og filosofiske perspektiv (18). Tre sentrale analyseformer er 
meningskoding, meningsfortetning og meningsfortolkning. I praksis ser vi at disse er forbundet $(3,8,19)$.

Uavhengig av analysemetode er det flere tolkningsnivåer som også blir betraktet som analytisk verktøy. Ifølge Kvale \& Brinkman (8) og Bo Glavind (20) er det tre fortolkningsnivåer: Selvforståelsesnivået som er en sammenfatning av forskers og informants forståelse av det som blir sagt. Common sence-nivå hvor det foregår en allmenn fortolkning, som har en bredere forståelsesramme enn informantens egen. Teoretisk forståelsesnivå hvor man benytter en teoretisk ramme ved fortolkning. De fleste analyser innebærer en form for dekontekstualisering og rekontekstualisering. Ved dekontekstualisering ser man på deler av datamaterialet. Ved rekontekstualisering settes delene inn i en ny sammenheng som samtidig er tro mot den sammenhengen deler av datamaterialet ble hentet ut fra (12). Det er i denne prosessen det skapes ny kunnskap. Forskers teoretiske perspektiv, faglige og kulturelle bakgrunn er sentrale forutsetninger for fortolkninger og de spørsmål som kan stilles til datamaterialet. I analysen stilles spørsmål om de valgte teoriene er gyldig for det som man undersøker og om tolkningene følger logisk fra teorien. Dette er et uttrykk for den hermeneutiske dimensjonen.

\section{TROVERDIGHET}

Når man skal vurdere et forskningsprosjekts troverdighet, vil ulike forskningstradisjoner prege valg av begreper. I kvalitativ forskning er troverdighet det overordnede begrepet for gyldighet, pålitelighet og overførbarhet $(9,11,19)$. I kvantitativ forskning brukes begrepene validitet, reliabilitet og generaliserbarhet. Imidlertid vil man også finne de kvantitative begrepene i kvalitativ forskning. Det er da viktig å være klar over at begrepene har ulik betydning i kvalitativ og kvantitativ forskning. Mens troverdighet i kvalitativ forskning omfatter hele studien, vil validitet i kvantitativ forskning oftest omfatte behandling av datamaterialet (10). Vurderingen av troverdighet i det kvalitative forskningsintervjuet innebærer i hvilken grad forsker har frembrakt resultater som er pålitelige, gyldige og overførbare. Det er glidende overganger av betydningen mellom disse begrepene, en forutsetning for å få gyldige data er at de er pålitelige (21). Det er sentralt om forskningen er relevant og har betydning. I kvalitative studier prøver man å oppfylle dette gjennom dokumentert refleksivitet, som innebærer at forskeren har et kritisk blikk på egne ideer, rolle, bruk av metoder, møtet med informanter, tolkning og så videre. (11).

\section{GYLDIGHET}

Gyldighet peker på om man har undersøkt det man skulle undersøke $(3,9,10)$. Gyldighet underveis i et intervju innebærer at forskeren regelmessig sjekker sin egen oppfatning med spørsmål som: «Har jeg forstått deg rett når du sier at?» Dette kan bidra til at råmaterialet i størst mulig grad representerer en felles forståelse mellom forsker og informant. I kvalitative forskningsintervjuer er forskerens kompetanse og egnethet avgjørende for data som skapes. Forskerens kompetanse refererer til den håndverksmessige kvaliteten, det vil si hvordan man har utført intervjuet, gjort nødvendige notater underveis, hvordan man har transkribert og dokumentert, begrunnet og redegjort for hva man har gjort. Uten dette er det ingen gyldighet i kvalitativ forskning. Når kontekst, intensjon og perspektiv er tydeliggjort har leseren selv mulighet til å vurdere gyldigheten (8). Andre måter å sikre gyldighet på er blant annet metodetriangulering. informantvalidering og forskervalidering $(9,22,23)$.

Ved metodetriangulering anvendes ulike metoder for innhenting av data, eksempelvis både intervju og observasjon. Ved informantvalidering vil informanten lese igjennom det transkriberte intervjuet og/eller vurdere forskerens fortolkning. Informanten kan avdekke svakheter og dermed bidra til å styrke gyldigheten. Utfordringen er at forsker og informant kan fortolke samme materialet ulikt. Forskeren kan ikke basere seg utelukkende på informantenes egen virkelighetsbeskrivelse, men må se dette i forhold til de analytiske begreper og teoretiske perspektiver som er viktige i studien. Det er problemstillingen, metoden og kvaliteten på data som avgjør hva som er relevante gyldighetsprosedyrer, og teksten blir ikke nødvendigvis mer gyldig om informanten har rettet den opp (12). Forskeren kan også diskutere materialets gyldighet med det vitenskapelige miljøet. Ved forskervalidering vil flere forskere stille ulike spørsmål til den samme teksten, og tolkningen blir derav utfordret.

Gyldighetsvurderinger kan underbygges empirisk gjennom sammenligninger av ulike data om de samme fenomenene. Datamaterialets validitet må drøftes konkret i forhold til den spesielle konteksten 
der datainnsamlingen er foretatt. Forskjellene i datamaterialet kan skyldes at dataene er foretatt under ulike kontekstuelle forhold, det er ikke nødvendigvis validitetsproblemer (15). Troverdigheten kan øke dersom man viser at man har lett etter bevis for det motsatte. Dette kalles «å lete etter negative tilfeller». Jo sterkere falsifiseringsbestrebelser en uttalelse har overlevd, jo mer gyldig er kunnskapen $(10,12)$.

\section{PÅLITELIGHET}

Pålitelighet omfatter konsistens og nøyaktighet. Påliteligheten styrkes ved at alle praktiske forhold vedrørende forskningsintervju som for eksempel lydkvalitet på intervjuopptak, er nøye gjennomtenkt. Trussel mot troverdigheten kan være at forskeren har vært lite oppmerksom og slurvete i nedtegning og analyse av data. Forskeren kan forberede seg på dette ved å «lage en sti» (audit trail) som innebærer å be om en ekstern vurdering av alle relevante forhold i studien. Dette vil bidra til kriteriet om gjennomsiktighet, som er et av de håndverksmessige kriteriene (10). Når forskeren presenterer sin studie skal andre også kunne følge stien forskeren har gått i studien. Forskeren kan styrke påliteligheten ved å gi leseren en inngående beskrivelse av konteksten og en detaljert fremstilling av fremgangsmåten under hele forskningsprosessen $(10,18)$. Imidlertid kan for sterk fokusering på pålitelighet motvirke kreativ tenkning og variasjon (8).

Overførbarhet dreier seg om funnene har gyldighet utover utvalget, konteksten og er relevant og anvendbart i andre situasjoner. I kvalitativ forskning er overførbarhet knyttet til om man kan kjenne igjen meningen og om denne meningen gir innsikt av betydning.

\section{KONKLUSJON}

Kvalitativ forskning reiser mange etiske utfordringer spesielt i forhold til informanter i en sårbar livssituasjon. Troverdigheten i et kvalitativt forskningsintervju er knyttet til en åpen tilnærming, nøyaktighet, refleksivitet og evne til å møte dynamiske utfordringer i intervjusituasjonen. Forskers vitenskapsteoretiske ståsted, verdi og kunnskapssyn har betydning for data som skapes. Hele forskningsprosessen og det dynamiske aspekt i intervjusituasjonen må tydeliggjøres da den har stor betydning for troverdigheten.
Takk til professor Herdis Alvsvåg, Haraldsplass Diakonale høyskole, og førsteamanuensis Esther Hjälmhult, Høgskolen i Bergen, for nyttige kommentarer til utkast.

\section{REFERANSER}

1. Fog J. Med samtalen som utgangspunkt. Det kvalitative forskningsinterview. Danmark: Akademisk Forlag A/S, 2001

2. Fontana Andrea, Frey James H. The Interview In: Denzin K. Norman, Lincoln Yvonna S.(red) The Sage Handbook of Qualitative Research Third Edition. London: Sage Publication, 2005.

3. Ellingsen S, Drageset S. Kvalitativ tilnærming i sykepleieforskning - en introduksjon og oversikt. Norsk Tidsskrift for sykepleieforskning; 2008;10(3), 23-39.

4. Drageset S, Ellingsen S, Lindstrøm T.C. Kvantitativ tilnærming i sykepleieforskning - en diskusjon og oversikt. Norsk Tidsskrift for sykepleieforskning. 2008,10(4), 28-40.

5. Drageset S, Ellingsen S. Forståelse av kvantitativ helseforskning - en introduksjon og oversikt. Nordisk Tidsskrift for helseforskning. 2009;5(2), 100-13.

6. Olsen H. Veje til kvalitativ kvalitet? Om kvalitetssikring af kvalitativ interviewforskning. Nordisk Pedagogik. 2003;3, 1-20.

7. Creswell JW. Qualitative inquiry research design. London: Sage Publication, 2007.

8. Kvale S, Brinkmann S. Det kvalitative forskningsintervju. Oslo: Gyldendal Norsk Forlag AS, 2009

9. Denzin N.K, Y.S. Lincoln (red) The Sage Handbook of Qualitative Research. London: Thousands Oaks, Ca: SAGE, 2005.

10. Polit DF, Beck C.T. Nursing Research. Principles and Methods. 7th ed. USA: Lippincott Williams \& Wilkins 2004

11. Lerdal A. Metodekapitlet Sykepleien Forskning 2009; 4:239-241. 12. Malterud K. Kvalitative metoder i medisinsk forskning- en innføring. Oslo: Universitetsforlaget AS, 2003.

13. Martinsen K. Samtalen, skjønnet og evidensen. Oslo: Akribe, 2005

14. Martinsen K., Eriksson K. Å se og å innse Om ulike former for evidens. Oslo: Akribe, 2009.

15. Bourdieu P. Forståelse. In: Petersen Karin Anna, Glasdam Stinne, Lorentzen Vibeke (red.) Livshistorieforskning og kvalitative interview. Danmark: Forlaget PUC, CVU Midt Vest, 2007.

16. Brinkmann S, Kvale S. Confronting the ethics of qualitative research. Journal of Constructions Psychology. 2005;18:57-81.

17. Grimnes H. Personvern i helsefaglig forskning Sykepleien Forskning 2009; 4:162-165.

18. Giorgi A. Sketch of a psychological phenomenological method In Phenomenology and psychological research: essays / by Christopher Aanstoos [et al.]; edited and with an introduction by Giorgi, A. Pittsburgh, PA: Duquesne University Press, 1985: 9-22. 19. Rolfe G. Validity, trustworthiness and rigour: quality and the idea of qualitative research. Journal of Advanced Nursing. 2004; 53:304-10.

20. Bo Glavind I. Metodisk refleksivitet I det kvalitative forskningsinterview. Tidsskrift for sygeplejeforskning. 2004; 3:12-18.

21. Roberts $P$, Priest $H$. Reliability and validity in research. Nursing Standard, 2006; 20 (44), 41-5.

22. Røykenes K. Metodetriangulering - et metodisk minefelt eller berikelse av fenomener Sykepleien forskning 2008;4:224-27.

23. Kaarbø E. Kombinerte metoder Sykepleien forskning 2009:3:244-49. 